\title{
SOCIOPOLITICAL VALUES, ATTITUDES AND BEHAVIORS OF PORTUGUESE ECONOMICS STUDENTS
}

\author{
João Carlos Graça \\ Universidade de Lisboa, Instituto Superior de Economia e Gestão (ISEG), Centro de Investigação \\ em Ciências Sociais e Gestão (Socius/CSG), Lisboa, Portugal \\ Jorge Caiado \\ Universidade de Lisboa, Instituto Superior de Economia e Gestão (ISEG), Centro de Matemática \\ Aplicada à Previsão e Decisão Económica (Cemapre), Lisboa, Portugal \\ Rita Gomes Correia \\ Universidade de Lisboa, Instituto Superior de Economia e Gestão (ISEG), Centro de Investigação \\ em Ciências Sociais e Gestão (Socius/CSG), Lisboa, Portugal
}

\begin{abstract}
Previous research on the Portuguese case confirmed free-riding, free-marketer and right-wing political inclinations among economics students. Further scrutiny was endeavored here, perceiving also a considerably increased interest for politics, notwithstanding the lack of concern for public problems. Various aspects of free-riding proclivity were distinguished and discussed, relating them with youngsters' risk-loving and sensation-seeking tendencies, but also with a number of other facets specific to economics students, including: prevalence of achievement values, contextual influences on morals, peer pressure, perceived group status and social expectations regarding the economic profession.
\end{abstract}

Keywords: economics students, left-right perceptions, interest for politics, varieties of free-riding inclinations.

Valores, atitudes e comportamentos sociopolíticos dos estudantes portugueses de Economia

Resumo Pesquisas anteriores sobre o caso português confirmaram inclinações políticas de direita e pró-mercado entre os estudantes de economia, a par duma maior tendência para o free-riding. Investigação subsequente, ora exposta, permitiu perceber também uma atração acrescida pela política, não obstante a falta de interesse pelos problemas públicos. Diversos aspetos da inclinação free-rider foram distinguidos, relacionando-os com propensão juvenil para o risco e a busca de sensações, mas também com traços específicos dos estudantes de economia, incluindo: prevalência de valores de realização, influências contextuais na moralidade, pressão dos pares, perceção de status e expetativas associadas à profissão de economista.

Palavras-chave: estudantes de economia, perceções de esquerda e direita, interesse pela política, variedades de inclinação para o free-riding.

Valeurs, attitudes et comportements sociopolitiques des étudiants portugais en Économie

Résumé Des études antérieures ont confirmé la prévalence de tendances politiques de droite et pro-marché parmi les étudiants d'économie au Portugal, parallèlement à une inclination accrue pour le free-riding. Des recherches subséquentes, ici exposés, ont détecté aussi une intense attraction par la politique, malgré l'indifférence vers la vie publique. Plusieurs aspects de la pente vers le free-riding ont été distingués, en les rapportant à la propension des jeunes pour le risque et la recherche de sensations, mais également à des traits spécifiques des étudiants d'économie, nommément: valeurs d'accomplissement, influences contextuelles sur la moralité, pression des pairs, perception de statut et attentes relatives à la profession d'économiste.

Mots-clés: étudiants d'économie, perceptions de droite et de gauche, intérêt par la politique, variétés d'inclination vers le free-riding.

Valores, actitudes y comportamientos sociopolíticos de los estudiantes portugueses de Economía

Resumen Pesquisas anteriores en el caso portugués confirmaron inclinaciones políticas de derecha y pro-mercado entre los estudiantes de economía, en paralelo con una mayor tendencia al free-riding. Investigación subsiguiente, aquí expuesta, permitió percibir también una mayor atracción por la política, pero sin interés por 
asuntos públicos. Diversos aspectos de la inclinación free-rider fueron distinguidos, relacionándolos con la propensión juvenil hacia el riesgo y la búsqueda de sensaciones, pero también con aspectos específicos de los estudiantes de economía: prevalencia de valores de realización, influencias contextuales en la moralidad, presión de los pares, percepción de status y expectativas relativas a la profesión de economista.

Palavras-clave: estudiantes de economía, percepciones de izquierda y derecha, interés por la política, variedades de inclinación para el free-riding.

\section{Introduction: the problems}

Six decades ago now, George Stigler has pioneered the formal academic recognition of the fact that mainstream economics tends to induce a considerable amount of indoctrinating leaning, indeed allowing him to advance the need to explicitly consider the importance of the category of "the economist as preacher". Notwithstanding such leaning being easily relatable to the typical economics' theoretical framework, positing "rational", self-interested, maximizing and individualistic "representative agents", or homines economici, Stigler has also attributed that indoctrinating effect mostly to an instructive one: more informed economists would obviously tend to discard various possible suggestions (namely some with a redistributive character, or regarding price-controls) that instead a less mindful citizen would very probably be inclined to accept (Stigler, 1959, 1982; see also Kirchgässner, 2014).

To be sure, the venues opened by Stigler's contribution are multifaceted, with the political implications or ramifications stemming from official economics being famously intimated by many authors such as Gunnar Myrdal (1954), Crawford Brough Macpherson (1962) and more recently also Yanis Varoufakis (2002 [1998]) and Ha-Joon Chang (2011), among several others. Stigler's train of thought has, however, referred especially the more directly moral aspects of the problem, those related with the discussion of free-riding propensity; and secondly, also the possible enhancement of free-marketeering attitudes and values. Following Stigler's suggestion, an important line of research has really developed in the meantime, this current of studies usually recognizing the potential indoctrination effects of studying economics to be dual: first, it generally increases the proclivity to act in a more selfish manner, at least in the sense of having an higher generic bent to free-ride, defect and not cooperate with others (see, for example, Frey and Meier, 2004, 2005; Meier and Frey, 2004; Rubinstein, 2006); and second, it also prompts a leaning towards free-marketeering, in the sense of preference for private versus public economic regulation concerning the provision of scarce products, in other terms the capacity-plus-readiness to pay "market-clearing prices" as distinguished from abidance to dispositions stemming from public powers and/or common fairness rules (cf. Caplan, 2002; Gandal et al., 2004, 2005; Kahneman, Knetsch and Thaler, 1986; Kearl et al., 1979; Kirchgässner, 2005).

A considerable number of studies on this cluster of themes was performed and published in the last decades, its results on the whole configuring an in-depth comparison of the values, attitudes, preferences and behaviors of economists in a broad sense, including economics students, with those of other professionals 
and/or the population at large. A list of this variety of exercises, mostly with a predominant empirical orientation, must include Scott and Rothman (1975), Marwell and Ames (1981), Frey (1986), Carter and Irons (1991), Frey, Pommerehne and Gygi (1993), Simon (1993), Frank, Gilovich and Regan (1993, 1996), Yezer, Goldfarb and Popen (1996), Selten and Ockenfels (1998), Laband and Beil (1999), Frank and Schulze (2000), Frey and Meier (2003, 2005), Haucap and Just (2004), Kirchgässner (2005), Faravelli (2007), Cipriani, Lubian and Zago (2009), Wang and Murnighan (2009), Cappelen, Sørensen and Tungodden (2010), Bauman and Rose (2011); for a summary of this literature see Hellmich (2012); cf. also Hole (2013), Konow (2014), Graça, Lopes and Correia $(2014,2016)$.

\section{Some aspects concerning disciplinary divides}

We should, however, add the important proviso that this current of studies has been mostly endeavored by professional economists, notwithstanding the apparent easiness to connect its discussions with relevant analytical aspects developed within the ambit of social psychology; and indeed chiefly with a wider stream of research that is emphatically rooted in economic sociology, one explicitly relating the wider issue of trust-building in social interactions with the need to inhibit the so-called "opportunistic behavior" (Hodgson, 2004; Williamson, 1975; see also Marques, 2003; Graça, 2012; Graça, Lopes and Correia, 2016). This specific academic configuration has arguably induced also a variety of biasedness, or indeed what we may designate as a peculiar form of theoretical under-development plaguing this group of studies, most of which chiefly revolve around the persistent questions of whether or not economics students have free-marketeering and/or free-riding inclinations; and whether or not these can be attributed to education/nurture, as opposed to natural dispositions.

These are, to be sure, by no means questions easy to arbitrate. For example, Frank and Schulze (1998, 2000), Lanteri (2008) and Elegido (2009) assign such free-marketeering and free-riding trends mostly to nature and self-selection, and so do Rowen and Dietrich (2007), at least predominantly, whereas au contraire Varoufakis (2002 [1998]) and also Núñez, Miranda and Scavia (2007) decide resolutely for education/nurture, Haucap and Just (2003), Sjöberg and Engelberg (2006), López-Pérez and Spiegelman (2012) and Fischer et al. (2016) opt instead for a merely "agnostic" position, or really suggest a more "middle-of-the-road" one, recognizing the presence of both natural (self-selection) and nurture (education) influences, although reasserting the higher free-riding proclivity amongst economics students. Goossens and Méon (2010) also subscribe a middle-of-the-road position, although they notice the somewhat mysterious tendency of economics teaching to likewise produce a higher degree of homogeneity within the profession: "we observe that the answers of economics students tend to become more homogeneous over time. That effect is only observed in economics. It points out to some specificity of economics teaching" (id. ibid.: 19). Although not going deeply into the discussion of the magna quaestio opposing nature-versus-nurture, Wang and Murnighan (2009) do also emphasize the free-riding propensity induced by 
economics learning, with even just a small amount of exposure to it usually leading to more favorable opinions and feelings vis-à-vis greed and greedy conduct.

The political aspects of the problems are usually less thoroughly treated, although Lebaron (2012) and Mautz (2014) deal more in-depth with them, underscoring the important differences observable between average economists and the population at large as to various subjects (including free-marketeering orientation), as well as the consistent rise of the importance of economists in the sphere of public debates, usually supporting views that are officially presented as independent, value-free and strictly grounded on knowledge and technical expertise, thereby tending to erode the legitimacy based on democratic elections, or the politically exercised choices of the citizenry. Also in this regard, Delgado-Betancourth (2014) is particularly interesting given the emphasis that, following Deleuze and Guattari (1987) as well as Bruno Latour (2010), she assigns to the factish aspects of economics training, or its tendency to render inextricable the description of facts with the expression of mere beliefs, and also its "performative" traits, or its capacity to produce a particular range of economic environment, albeit recognizably one that is inseparably associated with a variety of moral twisting, and really with an undisguisable form of character erosion. Character damage arguably induced by economics is also an important explicit aspect of Yanis Varoufakis' enquiry: "Economics can seriously damage your character!" he vigorously warns the reader in the very beginning of chapter 12, bombastically named "The curse of economics" (2002 [1998]: 354). As opposed to these views, Fischer et al. (2016) claim that, although economics teaching does indeed produce a free-marketeering bias, this should not be attributed to an indoctrinating effect, but instead to a learning one: the students are supposedly not "brainwashed", and thus the free-marketer ideas are arguably not "hammered" into their brains: "An alternative interpretation would be that students acquire information that induces them to realign their political attitudes with their newly acquired knowledge. In this case, the training effect should rather be referred to as a learning effect" (id. ibid.: 24; italics in the original). This text indeed appears itself to express a considerable inclination, by average economics trainees, to a variety of group-thinking that is perhaps mostly associated with their intense quest for "perceived group status", such as noticed by other authors (see below).

Sjöberg and Engelberg (2006) have more specifically underscored the aspect that economists are not only more bent to free-ride: they are also more success-oriented, more prone to sensation-seeking and risk-taking; and they also possess generically a higher level of "emotional intelligence" than average students. In turn, Hole (2013) has underlined the fact that economics students seem to have a more "conditional" or less "categorical" approach to moral issues, normally behaving the right way, but never completely ceasing to consider their own angle of interest, thus being more prone to defect or behave egoistically in case that a majority of other intervenient parties does so. This seems to fundamentally confirm the conclusions presented by Hertel, Aarts and Zeelenberg (2002), according to whom the norms of fairness accepted are never a simple cultural implant, indeed usually expressing also each one's interest, but predominantly in a defensive, merely self-protective way. In other words, more or less everyone tends to play according to a rule of "when in Rome be Roman", but economists seem particularly inclined to the adoption of this generic principle. Gandal and Roccas 
(2002) have noticed economists to be more prone than average students to achievement and power values, less inclined to universalism (thus less preoccupied with generic notions of social justice or equality), but sensitive enough to benevolence, therefore usually making good friends and neighbors, although not exactly good citizens, even less so good persons. Moreover, Gandal et al. $(2004,2005)$ have also underscored average economists' penchant to self-enhancement and to a career work orientation, the high importance they normally attribute to "perceived group status" rendering them inclined to status-emphasizing organizations. This feature may, on occasions, produce peculiar organizational problems: "Thinking that organizational status has a crucial role in creating and maintaining organizational identification might lead economists to emphasize organizational status at the expense of other factors such as organizational cohesiveness, meaningful mission, or opportunities for personal growth" (2004: 20).

Finally, we should mention the opinions expressed by Amitai Etzioni (2015), according to whom economics teaching, rather than producing free-riding and selfish inclinations in students, mostly tends to reinforce the already existing ones. However, far from using this argument as a device for the (moral, political and scientific) acquittal of economics teaching, the issue with Etzioni turns out to be mostly the one-sidedness that these academic courses usually assume, contrasted with much more variegated intellectual landscape normally detectable in areas as, for example, social philosophy, political science and sociology. This deliberate biasedness, or indeed the cultivated mind narrowness typical of mainstream economics, is subsequently much reinforced by peer-pressure, the very consciousness of the prevailing doctrinaire bias of the discipline tending to be psychologically repressed. This is indeed mostly tacitly understood as a sheer expression of some unsurpassable "nature of things", of which the selfish values, attitudes and behaviors of agents thus become a "naturalized" defining trait:

The fact that those who become professional economists are more affected is most likely not merely due to much more exposure to the neoclassical message, but also to the fact that these students join a peer group and subculture that undergirds these views. Finally, one should note that not all economists will agree that what is considered here "debasing" is actually debasing. Some share with libertarians the conservative, laissez-faire view that, if everyone will follow their own self-interest and seek pleasure, the invisible hand will ensure that the greatest happiness for the greatest number is realized. Some even go so far as to argue that greed is good. If anybody doubted that this viewpoint is mistaken, the economic developments since 2008 should have disabused them of this notion (id. ibid. : 232).

\section{Previous research on the Portuguese case}

Debating whether or not the study of economics has a relevant effect on the social and political values, attitudes and behaviors attendant of the trust-building processes in our societies, and moreover explicitly referring this problem to the Portuguese case, 
Graça, Lopes and Correia $(2014,2016)$ have generally confirmed the initial group of hypothesis of simultaneous bigger free-riding and increased free-marketeering propensities amongst economics' students, both compared with other students and with the general population. However, the empirical evidence conveyed by these authors, a broad survey performed in 2006, 2009 and 2012 and referring to economics students, general population and other students (see Graça, Lopes e Correia, 2016: 522-523 for details), as well as its subsequent analytical treatment, have left largely undecided various other questions: namely the one regarding the prevalence of the "self-selection" hypothesis, positing the so-called "natural born economists" who arguably would anyway turn into free-marketeering and behave selfishly in surveys, experiments and the real life (with these psychological traits rendering them also logically attracted to the study of economics and the correspondent theoretical norms), versus the "indoctrination" hypothesis, sustaining that the economists' biases and inclinations, namely their leaning to both selfishness and political free-marketeering, are mostly produced and nurtured via the education processes. This problem was treated in the aforementioned works basically by comparing the results obtained denoting students in the successive years during graduation and post-graduation courses, but it is fair to say that the results remained largely inconclusive as to this aspect. Other important aspects disclosed by this research were the relevant biases existing within economics students, based on gender and levels of income: those belonging to families correspondent to higher income levels, and especially male students, being considerably more free-marketer and also systematically more interested in politics than those from families pertaining to low echelons of income, particularly women.

Another important feature of this line of research referring to Portugal consisted of highlighting that free-riding and free-marketeering propensities are indeed significantly different psycho-sociological aspects, a fact that became well patent by contrasting the groups designated as "economists" (indeed economics students), "other students" and general population or "commoners": whereas other students systematically occupied an intermediate position regarding the free-riding dimension, with "commoners" representing the top of its aversion and "economists" its uppermost tolerance, if we consider aspects referring to economic regulation it is the group of "other students" who signpost a maximum of inclination for state regulation and market aversion, thus becoming the direct opposite of free-marketer economics apprentices. "Commoners", let us now recall, have been inquired in 2006, "other students" in 2009, "economists" in 2006 and again in 2012, with these results valid for the samples of both years.

Another task left unfinished in the abovementioned previous work was the one of disentangling the various possible components included in what was taken as the group of markers for free-riding proclivity. In this paper we therefore pursue the important goal of analyzing and separating those various different components of free-riding leaning, simultaneously by enlarging the number of items considered and by attempting to more precisely detect as to what aspects are "other students" nearer to economics students, as opposed to the cases when they are more separated from their junior counterparts and closer to older citizens. This analysis aims at contributing to more clearly distinguish strict free-riding leaning from other possible attitudes typical of 
youngsters, namely risk-love, sensation-seeking, and more broadly the enjoyment of adventure that is potentially associated with the sheer breaking of social rules.

\section{Economic regulation, left-right perceptions, interest for politics}

Compared to the aforesaid works, the more directly political aspects of the enquiry were also developed in the present paper, and a number of additional clarifications pursued. On the one hand, it became overwhelmingly clear that the self-perception or positioning alongside a "left-right" political dimension is closely connected with preferences in terms of economic regulation, those identifying themselves as left-leaning opting massively for the state, and those consciously on the right-wing of the political spectrum choosing the market. The generic political mapping of the various surveyed groups ("economics students", "other students" and "commoners") thus closely matches the stated preferences in terms of economic regulation: free-marketeering "economists" visibly lean to the right, both in terms of actual vote and self-perception, whereas pro-state "other students" lean to the left (again, simultaneously regarding vote and self-image), with "commoners" occupying the center.

This is one aspect worth noting, considering the relevant fact that the so-called "economic imperialism" in academia has recognizably promoted in recent decades the intensive "exportation" unto other disciplines, particularly political science and macro-sociology, of various reasoning models originating mostly from micro-economics, the current flourishing of "public choice-theory" in political science being one flamboyant example of this trend, although certainly not the single one (cf. Lazear, 2000; Hellmich, 2012).The aforesaid "economic imperialism" has not, however, reached such dimension as to render it capable of obfuscating the important differences separating economics from other disciplines: therefore, "other students" clearly maintain values and attitudes that are easily distinguishable from those typical of economics trainees. Indeed, and as evidenced below in table 1, the percentages of respondents' opinion about the "desirable regulation of the economy" across groups (more state, more market or more "third sector") clearly reveal a pro-market penchant in economics students, neatly opposed to the pro-state attitude of other students.

From table 1 it can be seen that $63,17 \%$ and $54,58 \%$ of economics students of 2006 and 2012, respectively, are more pro-market inclined, compared with commoners $(28,79 \%)$ and other students $(27,05 \%)$. Pearson statistic $(135,31)$ suggests that the association between row variables and column variables is statistically significant. More aged "commoners", occupying an intermediate site as to the market-versus-state opposition, are also noticeably the most pro-third-sector of all the four groups.

This set of preferences is matched by the predominant political inclinations of the various groups. Regarding these, and using a combination of box plots (for medians) and dot plots (for means) in order to considerer the variable designated as "self-image in left-right terms", we can easily verify (see figure 1) the significant differences registered between commoners (2006), other students (2009) and economists (2006 and 2012); but also the existence of a higher variability within the group of economics students. 
Desirable regulation of the economy

\begin{tabular}{lccccr}
\hline & $\begin{array}{c}\text { Commoners } \\
2006\end{array}$ & $\begin{array}{c}\text { Economics } \\
\text { students 2006 }\end{array}$ & $\begin{array}{c}\text { Other students } \\
2009\end{array}$ & $\begin{array}{c}\text { Economics } \\
\text { students 2012 }\end{array}$ & Total \\
\hline More State & 52.27 & 26.35 & 60.25 & 38.50 & 42.05 \\
More Market & 28.79 & 63.17 & 27.05 & 54.58 & 46.84 \\
More 3rd Sector & 18.94 & 10.48 & 12.70 & 6.92 & 11.11 \\
Total & 100.00 & 100.00 & 100.00 & 100.00 & 100.00 \\
\hline
\end{tabular}

Pearson chi2 $(6)=135.31^{*}$

* Significant at the $1 \%$ level; ${ }^{* *}$ significant at the $5 \%$ level; ${ }^{* * *}$ significant at the $10 \%$ level

Figure 1 combines separate box plots and dot plots of self-image in political terms, displaying the differences among medians (box plots) and among means (dot plots). The median proportion of "right-wing leaning" tends to be visibly higher, but also more variable in economic students (2006 and 2012) than with "commoners" and with other students. The differences among means follow similar patterns. The global political leaning of each of the four groups enquired is thus fully confirmed.

This is, however, only one aspect of the situation, given the important simultaneous feature that the differences amongst the various groups referring to their "interest for politics" largely correspond to those regarding their self-perception alongside the left-right divide. In other words, economics students, being globally the most rightwing-prone group considered, are also ostensibly the group where the interest for politics is more forceful. Equally important, the results for the dimensions of "importance acknowledged to collective national problems" and of "perceived influence of citizens in politics" are rather more imprecise, the clear divide occurring with the previous two dimensions tending to instead become blurred, get reconfigured or vanish altogether. As pointed out in table 2, we performed one-way analysis of variance to test whether and how much the self-image in left-right political terms (row 1) the interest regarding politics (row 2), the importance acknowledged to collective national problems (row 3 ) and the perceived influence of citizens in politics (row 4) differ across samples: commoners 2006, economics students 2006, other students 2009 and economics students 2012.

Based on these data, we can categorically reject the hypothesis of equal means across samples as to the variable "self-image in political terms" (F=23,88), the "interest regarding politics" $(\mathrm{F}=103,28)$, and also the "importance acknowledged to collective national problems" $(\mathrm{F}=9,60)$ at the $1 \%$ level, but not the hypothesis of equal means across samples concerning the "perceived influence of citizens in politics". The hypothesis of equal variances is not rejected in "self-image in political terms" comparison, which supports Anova's validity. We found statistically significant differences between commoners 2006 and both other students 2009 and economic students (2006 and 2012) for the "importance acknowledged to collective national problems". As for the "interest regarding politics" and the "self-image in political terms", the same is true between commoners 2006 and economic students (2006 and 2012), and also between other students 2009 and economic students (2006 and 2012). 


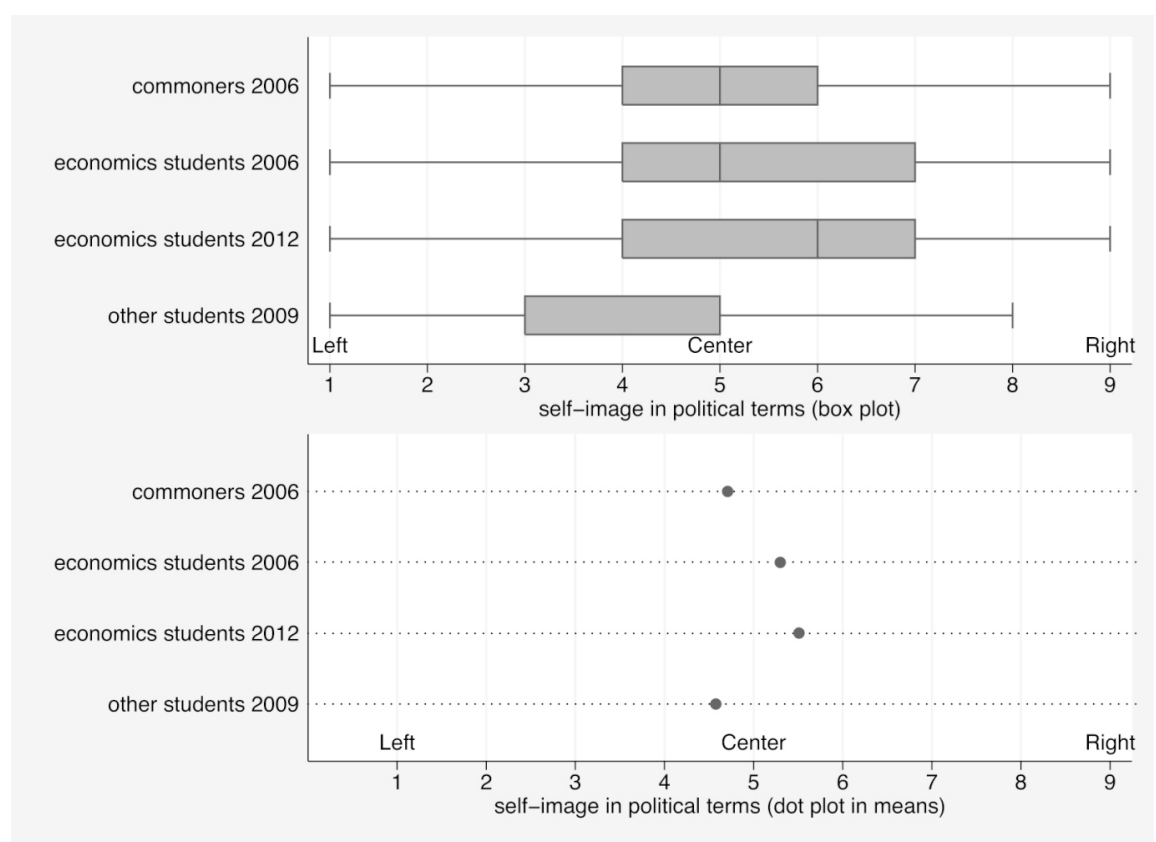

Figure 1 Box plots (medians) and dot plots (means) of self-image in left-right terms

Otherwise said, the four generic groups ("economists" of both years, "other students", "commoners") are clearly distinguishable as to the items of "left-right political self-perception" and "interest for politics", with economics apprentices of both years simultaneously leaning to the right and having more appetite for politics, whereas other students lean to the left but are politically anorectic. Regarding the "perceived influence of citizens in politics", there are no relevant differences among the various groups. Concerning the "importance acknowledged to collective national problems", the group of "commoners" is clearly distinguishable from both economics novices and other students. We can therefore confirm, as to this item, the neat basic opposition between one group of aged citizens, who cares more for public issues/problems, and a junior population that normally takes a more carefree approach to life. However, and as opposed to this division, economics students claim to be more interested in politics than "commoners", whereas other students are less so interested; and they lean comparatively to the right, whereas other students lean to the left instead.

\section{Free-riding leaning and political attitudes}

These results mostly confirm the indications presented by Graça, Lopes and Correia $(2014,2016)$ as to the lexical resources and the mental framing of economics having somehow already "colonized" the realm of politics, therefore inducing (all other things remaining equal) a bigger inclination of economics students to these 


\begin{tabular}{|c|c|c|c|c|c|c|c|c|}
\hline \multicolumn{9}{|c|}{ Row 1: Self-Image in left-right terms } \\
\hline \multirow[b]{2}{*}{ Sample } & \multicolumn{3}{|c|}{ Descriptive statistics } & \multicolumn{2}{|c|}{ ANOVA test } & \multicolumn{3}{|c|}{ Scheffé test } \\
\hline & Mean & Std. dev. & Obs & F-test & Bartlett's & $\begin{array}{c}\text { Comm. } \\
2006\end{array}$ & $\begin{array}{c}\text { Econ. stud. } \\
2006\end{array}$ & $\begin{array}{l}\text { Other stud. } \\
2012\end{array}$ \\
\hline Commoners 2006 & 4.71 & 1.711 & 257 & \multirow{4}{*}{$23.88^{*}$} & \multirow{4}{*}{4.20} & \multirow{4}{*}{$\begin{array}{c}0.592^{*} \\
-0.130 \\
0.801^{*}\end{array}$} & \multirow{4}{*}{$\begin{array}{c}-0.722^{*} \\
0.210\end{array}$} & \multirow[b]{4}{*}{$-0.932^{*}$} \\
\hline Economics students 2006 & 5.30 & 1.673 & 300 & & & & & \\
\hline Other students 2009 & 4.58 & 1.508 & 199 & & & & & \\
\hline Economics students 2012 & 5.51 & 1.602 & 524 & & & & & \\
\hline \multicolumn{9}{|c|}{ Row 2: Interest regarding politics } \\
\hline \multirow[b]{2}{*}{ Sample } & \multicolumn{3}{|c|}{ Descriptive statistics } & \multicolumn{2}{|c|}{ ANOVA test } & \multicolumn{3}{|c|}{ Scheffé test } \\
\hline & Mean & Std. dev. & Obs & F-test & Bartlett's & $\begin{array}{c}\text { Comm. } \\
2006\end{array}$ & $\begin{array}{c}\text { Econ. stud. } \\
2006\end{array}$ & $\begin{array}{l}\text { Other stud. } \\
2012\end{array}$ \\
\hline Commoners 2006 & 2.30 & 0.999 & 325 & & & & & \\
\hline Economics students 2006 & 2.78 & 0.811 & 368 & & & $0.484^{*}$ & & \\
\hline Other students 2009 & 1.98 & 0.807 & 354 & $103.28^{*}$ & $25.75^{*}$ & $-0.312^{*}$ & $-0.797^{*}$ & \\
\hline Economics students 2012 & 2.88 & 0.807 & 642 & & & $0.582^{*}$ & 0.097 & $-0.894^{*}$ \\
\hline \multicolumn{9}{|c|}{ Row 3: Importance acknowledged to national problems } \\
\hline \multirow[b]{2}{*}{ Sample } & \multicolumn{3}{|c|}{ Descriptive statistics } & \multicolumn{2}{|c|}{ ANOVA test } & \multicolumn{3}{|c|}{ Scheffé test } \\
\hline & Mean & Std. dev. & Obs & F-test & Bartlett's & $\begin{array}{c}\text { Comm. } \\
2006\end{array}$ & $\begin{array}{c}\text { Econ. stud. } \\
2006\end{array}$ & $\begin{array}{l}\text { Other stud. } \\
2012\end{array}$ \\
\hline Commoners 2006 & 52.24 & 186.029 & 325 & & & & & \\
\hline Economics students 2006 & 26.69 & 113.216 & 377 & & & $-25.60^{*}$ & & \\
\hline Other students 2009 & 13.11 & 7.514 & 334 & $9.60^{*}$ & $2100^{*}$ & $-39.13^{*}$ & -13.58 & \\
\hline Economics students 2012 & 19.06 & 56.020 & 644 & & & $-33.13^{*}$ & -7.62 & -5.95 \\
\hline \multicolumn{9}{|c|}{ Row 4: Assessed influence of citizens in politics } \\
\hline \multirow[b]{2}{*}{ Sample } & \multicolumn{3}{|c|}{ Descriptive statistics } & \multicolumn{2}{|c|}{ ANOVA test } & \multicolumn{3}{|c|}{ Scheffé test } \\
\hline & Mean & Std. dev. & Obs & F-test & Bartlett's & $\begin{array}{c}\text { Comm. } \\
2006\end{array}$ & $\begin{array}{c}\text { Econ. stud. } \\
2006\end{array}$ & $\begin{array}{c}\text { Other stud. } \\
2012\end{array}$ \\
\hline Commoners 2006 & 2.54 & 0.864 & 278 & & & & & \\
\hline Economics students 2006 & 2.46 & 0.767 & 361 & & 607 & -0.086 & & \\
\hline Other students 2009 & 2.45 & 0.763 & 324 & 1.39 & 6.07 & -0.093 & -0.006 & \\
\hline Economics students 2012 & 2.43 & 0.797 & 632 & & & -0.116 & -0.030 & 0.023 \\
\hline
\end{tabular}

* Significant at the $1 \%$ level ${ }^{* *}$; significant at the $5 \%$ level; ${ }^{* * *}$ significant at the $10 \%$ level.

activities, in spite of their basic lack of any real interest for them: indeed, average economists seem to tend to perceive themselves as naturally endowed with peculiar capacities, thus making them also have a particular, expectable "vocation" for the exercise of politics. Nevertheless, and contra the suggestions presented in the mentioned works, this inclination has apparently nothing to do with any possible increased perception of citizens' capacity to influence politics, an aspect regarding which visible differences across the various samples are really not detectable.

This increased appetite for politics, unmatched by any real interest for public issues, but accompanied by a clear right-wing leaning and an option for market 

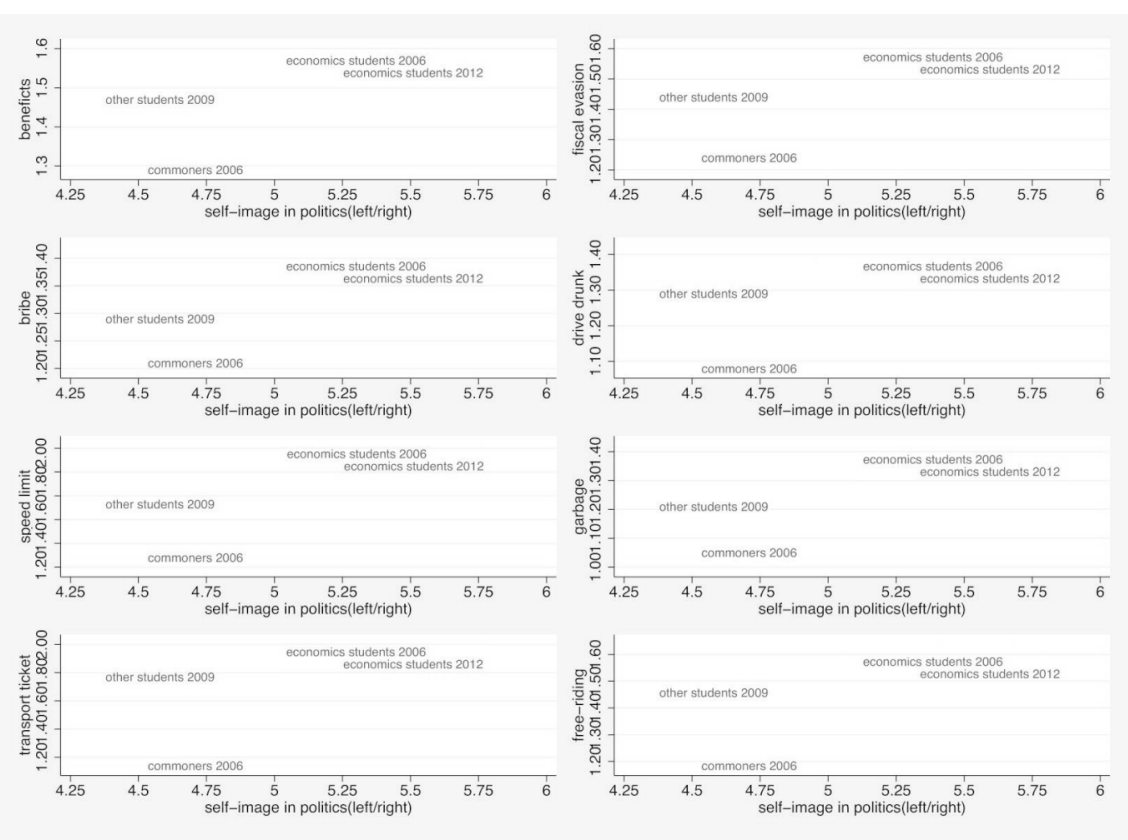

Figure 2 Scatterplots of data for legitimacy recognized to free-riding and political self-image

regulation, is further supplemented in the case of economics students by a bigger inclination to free-riding, as evidenced by figure 2 , showing scatterplots of self-image in political terms (left/right) against various aspects of legitimacy recognized to free-riding: claiming undue social benefits, engaging in fiscal evasion, accepting bribes, driving drunk, exceeding speed limits, throwing garbage in the street, avoiding payment for transport-ticket, and the average level of free-riding propensity.

If we compare this group of scatterplots with the one referring to data for "interest regarding politics" plotted against "legitimacy recognized for free-riding", we become immediately capable of identifying one fundamental affinity between the two confrontations: in both cases, the basic triangular disposition of the four groups is neatly identifiable for average free-riding inclination, self-perception in left-right dimension and interest for politics (see bottom right of both figure 2 and figure 3 ).

In other terms, free-ride-averting "commoners" occupy a middle-of-the-road position both as to "interest for politics" and as to "left-right self-image"; free-riding prone economists (of both years) diverge to the right and towards an increased political interest; other students, being halfway in matters of free-riding propensity, on the contrary shift to the left, but also towards a lessened political interest. This basic disposition is easily contrasted with the ones we face in the cases where the dimensions taken into consideration are the acknowledged "importance of national problems" and the perceived "influence of citizens in politics".

These we also plotted against legitimacy recognized to free-riding in figure 4, now using just the average, compound free-riding proclivity. In the case of recognized 

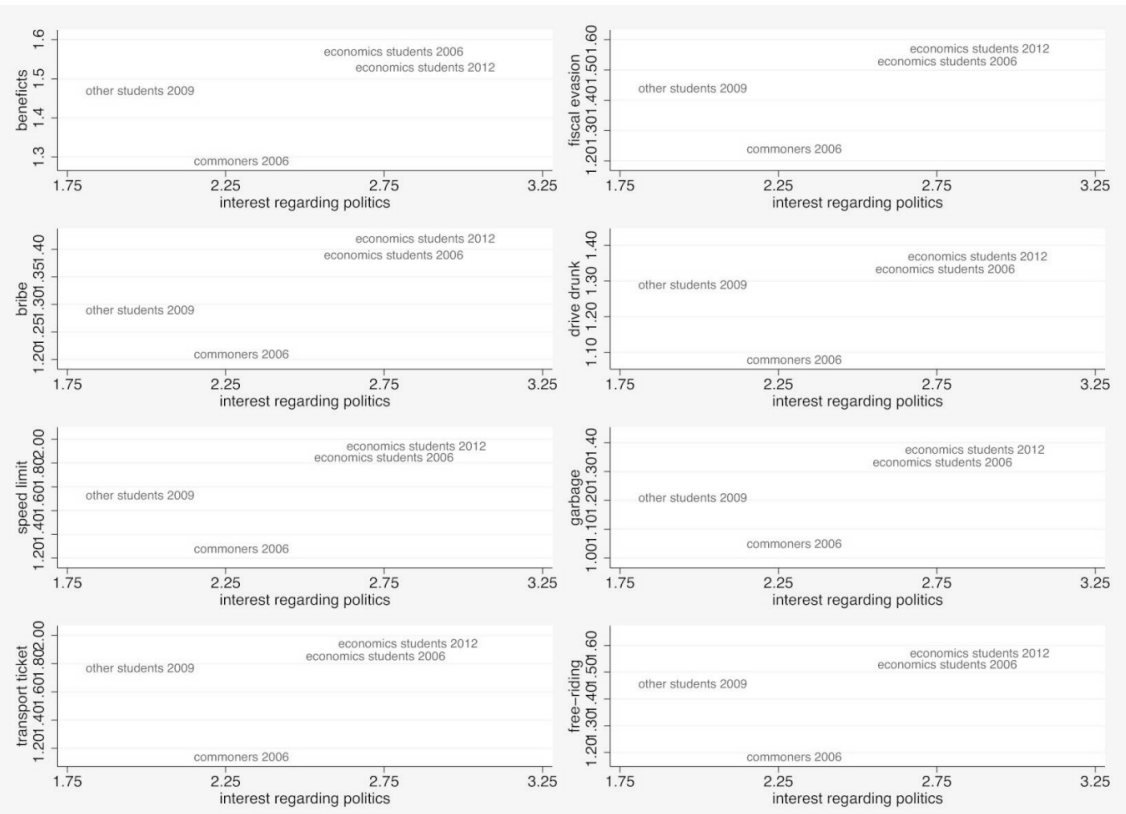

Figure 3 Scatterplots of data for legitimacy recognized to free-riding and interest for politics

"importance of national problems", the one most important aspect worth highlighting is the obvious cleavage between more concerned older commoners and carefree younger students of all courses, such as evidenced in figure 4 , left. Regarding the assessment of the "influence of citizens in politics", data essentially displays very similar patterns for all the groups considered, with only a very slightly higher value for the group of "commoners", as evidenced by figure 4, right.

These elements partly disprove what was conjectured in Graça, Lopes and Correia $(2014,2016)$ concerning an increased interest of economics novices for politics. It is really not that they care more for collective national problems; but definitely nor is it that they tend to assume a bigger capacity of the citizenry to influence the realm of politics. Their improved political appetite has nothing to do with any of those dimensions. It does however match and increased leaning to the right-wing (figures 2 and 3, above), confirming the notion that the academic training in economics usually produces one generic persuasion of being capable of (and/or of having a particular vocation to) directing the public affairs via the exercise of politics, and to do it in a certain manner that in undeniably biased to the right.

Moreover, and quite important, this is manifestly accompanied by an increased toleration for free-riding attitudes, vividly suggesting that we are not dealing here with some generic inclination for politics matched with any possible idea of "public service", but chiefly with an openness to a possible political career that is really mostly associated with a self-serving and self-promoting attitude. There are, however, some 


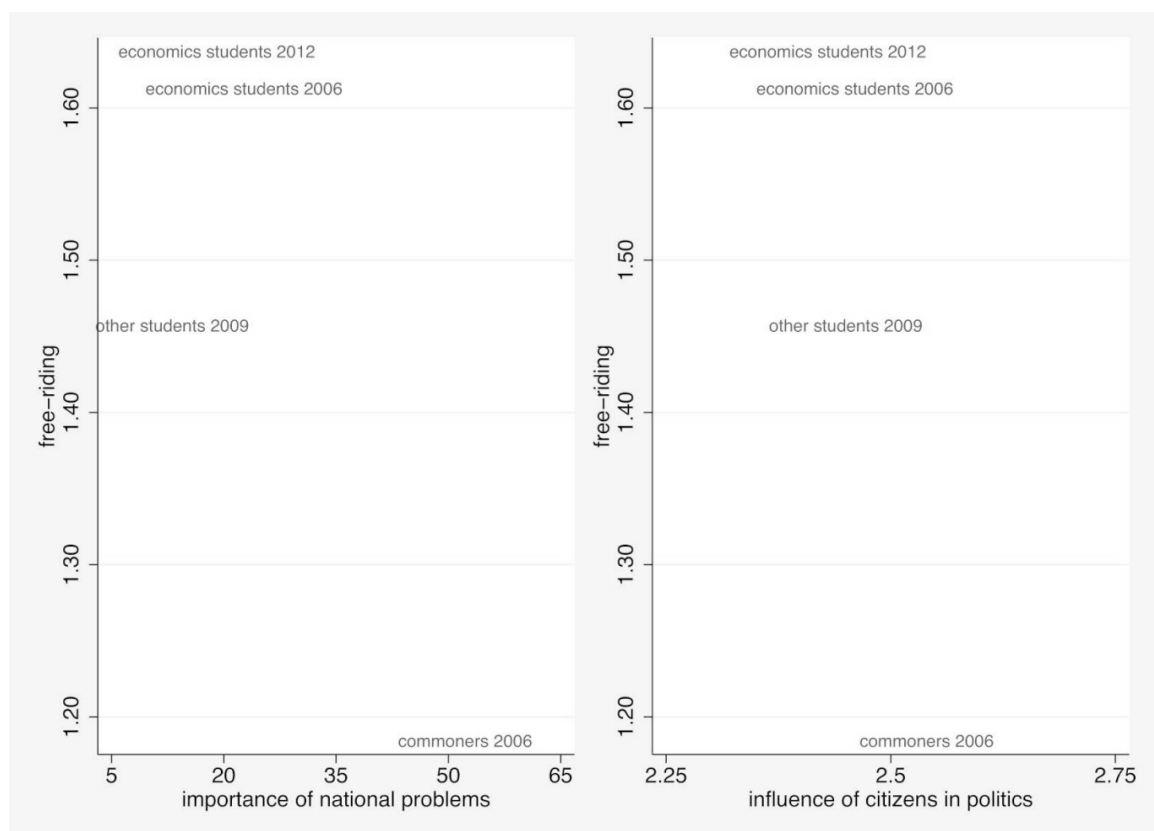

Figure 4 Scatterplots of data for average legitimacy recognized to free-riding and acknowledged importance of national problems (Left); idem and perceived influence of citizens in politics (Right)

important nuances to be added to this picture. As noticed in the aforementioned works, and we repeat, economics' undergraduates generically diverge from "commoners" simultaneously by leaning to the right and being more free-marketer, but also via being rather more inclined to free-riding, as measured then by considering the dimensions of acceptance of claiming undue social benefits, acceptance of fiscal evasion, tolerance for throwing garbage in the street and vis-à-vis avoiding paying for transport ticket. Contrasted with that picture, other students lean to the left and are more pro-state, whereas regarding free-riding they exhibit a tendency that is considerably higher than commoners, but clearly lower than their colleagues of economics.

\section{Some distinctions within free-riding leaning}

Some relevant differences were, however, importantly identified among the four free-riding dimensions referred above, with "other students" much closer to "commoners" regarding aversion for garbage throwing, for instance, whereas they considerably approach their economics colleagues as to avoiding payment for transport tickets. We have proceeded here with enlarging this study, by adding three new magnitudes likely denoting free-riding propensity, namely the levels of tolerance for bribe, for drunk driving and for exceeding speed limits. The various dimensions considered for free-riding confirmedly exhibit a remarkable level of 
Table 3 Legitimacy recognized to free-riding: summary statistics, analysis of variance and Scheffé multiple-comparison tests

\begin{tabular}{|c|c|c|c|c|c|c|c|c|c|}
\hline \multicolumn{5}{|c|}{ Descriptive Statistics } & \multicolumn{2}{|c|}{ Anova test } & \multicolumn{3}{|c|}{ Scheffé test } \\
\hline Variable & Groups & Mean & S.d. & Obs. & F-test & $\begin{array}{c}\text { Bartlett's } \\
\text { Test }\end{array}$ & $\begin{array}{c}\text { Comm. } \\
2006\end{array}$ & $\begin{array}{l}\text { Econ. } \\
\text { stud. } 2006\end{array}$ & $\begin{array}{c}\text { Other stud. } \\
2009\end{array}$ \\
\hline Benefits & $\begin{array}{l}\text { Commoners } 2006 \\
\text { Econ. students } 2006 \\
\text { Other students } 2009 \\
\text { Econ. students } 2012\end{array}$ & $\begin{array}{l}1.29 \\
1.57 \\
1.47 \\
1.53\end{array}$ & $\begin{array}{l}0.643 \\
0.756 \\
0.733 \\
0.782\end{array}$ & $\begin{array}{l}322 \\
364 \\
341 \\
630\end{array}$ & $9.26^{*}$ & $16.80^{*}$ & $\begin{array}{c}0.274^{*} \\
0.177^{* *} \\
0.237^{*}\end{array}$ & $\begin{array}{l}-0.097 \\
-0.037\end{array}$ & -0.059 \\
\hline $\begin{array}{c}\text { Fiscal } \\
\text { Evasion }\end{array}$ & $\begin{array}{l}\text { Commoners } 2006 \\
\text { Econ. students } 2006 \\
\text { Other students } 2009 \\
\text { Econ. students } 2012\end{array}$ & $\begin{array}{l}1.24 \\
1.52 \\
1.44 \\
1.55\end{array}$ & $\begin{array}{l}0.669 \\
0.809 \\
0.718 \\
0.815\end{array}$ & $\begin{array}{l}322 \\
367 \\
343 \\
630\end{array}$ & $12.42^{*}$ & $20.74^{*}$ & $\begin{array}{c}0.278^{*} \\
0.195^{* *} \\
0.309^{*}\end{array}$ & $\begin{array}{l}-0.083 \\
0.031\end{array}$ & -0.114 \\
\hline Bribe & $\begin{array}{l}\text { Commoners } 2006 \\
\text { Econ. students } 2006 \\
\text { Other students } 2009 \\
\text { Econ. students } 2012\end{array}$ & $\begin{array}{l}1.21 \\
1.39 \\
1.29 \\
1.42\end{array}$ & $\begin{array}{l}0.614 \\
0.674 \\
0.564 \\
0.678\end{array}$ & $\begin{array}{l}320 \\
363 \\
340 \\
630\end{array}$ & $9.14^{*}$ & $17.36^{*}$ & $\begin{array}{l}0.185^{*} \\
0.082 \\
0.211^{*}\end{array}$ & $\begin{array}{c}-0.103 \\
0.026\end{array}$ & $-0.129 * *$ \\
\hline $\begin{array}{l}\text { Drive } \\
\text { Drunk }\end{array}$ & $\begin{array}{l}\text { Commoners } 2006 \\
\text { Econ. students } 2006 \\
\text { Other students } 2009 \\
\text { Econ. students } 2012\end{array}$ & $\begin{array}{l}1.08 \\
1.41 \\
1.29 \\
1.42\end{array}$ & $\begin{array}{l}0.387 \\
0.747 \\
0.615 \\
0.711 \\
\end{array}$ & $\begin{array}{l}321 \\
368 \\
346 \\
635\end{array}$ & $22.03^{*}$ & $153.85^{*}$ & $\begin{array}{l}0.327^{*} \\
0.205^{*} \\
0.339^{*}\end{array}$ & $\begin{array}{l}-0.121 \\
0.013\end{array}$ & $-0.134^{* *}$ \\
\hline $\begin{array}{c}\text { Speed } \\
\text { Limit }\end{array}$ & $\begin{array}{l}\text { Commoners } 2006 \\
\text { Econ. students } 2006 \\
\text { Other students } 2009 \\
\text { Econ. students } 2012\end{array}$ & $\begin{array}{l}1.28 \\
2.20 \\
1.73 \\
2.22\end{array}$ & $\begin{array}{l}0.686 \\
0.959 \\
0.771 \\
0.869 \\
\end{array}$ & $\begin{array}{l}323 \\
362 \\
344 \\
634\end{array}$ & $109.40^{*}$ & $43.28^{*}$ & $\begin{array}{l}0.917^{*} \\
0.448^{* *} \\
0.942^{*}\end{array}$ & $\begin{array}{c}-0.469^{*} \\
0.025\end{array}$ & $-0.494^{*}$ \\
\hline Garbage & $\begin{array}{l}\text { Commoners } 2006 \\
\text { Econ. students } 2006 \\
\text { Other students } 2009 \\
\text { Econ. students } 2012\end{array}$ & $\begin{array}{l}1.05 \\
1.34 \\
1.21 \\
1.42\end{array}$ & $\begin{array}{l}0.315 \\
0.625 \\
0.497 \\
0.698\end{array}$ & $\begin{array}{l}324 \\
364 \\
350 \\
633\end{array}$ & $31.13^{*}$ & $234.33^{*}$ & $\begin{array}{c}0.288^{*} \\
0.159^{* *} \\
0.366^{*}\end{array}$ & $\begin{array}{c}-0.129^{* *} \\
0.078\end{array}$ & $-0.207^{*}$ \\
\hline $\begin{array}{c}\text { Transport } \\
\text { Ticket }\end{array}$ & $\begin{array}{l}\text { Commoners } 2006 \\
\text { Econ. students } 2006 \\
\text { Other students } 2009 \\
\text { Econ. students } 2012\end{array}$ & $\begin{array}{l}1.14 \\
1.86 \\
1.77 \\
1.90\end{array}$ & $\begin{array}{l}0.513 \\
0.873 \\
0.856 \\
0.885\end{array}$ & $\begin{array}{l}323 \\
365 \\
347 \\
629\end{array}$ & $68.35^{*}$ & $117.96^{*}$ & $\begin{array}{c}0.724^{*} \\
0.630^{* *} \\
0.757^{*}\end{array}$ & $\begin{array}{c}-0.094 \\
0.034\end{array}$ & -0.127 \\
\hline
\end{tabular}

* Significant at the $1 \%$ level **; significant at the $5 \%$ level; ${ }^{* * *}$ significant at the $10 \%$ level.

"internal" differences, such as revealed by comparing the values for aversion to garbage throwing, now added with aversion to bribe, disrespect for speed-limits and drunk driving, in which cases "other students" visibly diverge from troublesome economics apprentices and instead approach well-behaved commoners, with the dimensions of avoiding paying for transport-ticket, fiscal evasion and claiming undue social benefits, where the exact opposite occurs.

Our research was based on performing one-way analysis of variance (Anova) in order to test whether and how the means of the legitimacy recognized to free-riding differ across categories ("commoners 2006", "economics students 2006", "economics students 2012" and "other students 2009"). Table 3 presents the means and standard deviations within each category, the analysis of variance between groups and differences between each pair of means from the Scheffé multiple-comparison test. Figure 5 shows the dot plots among means. 


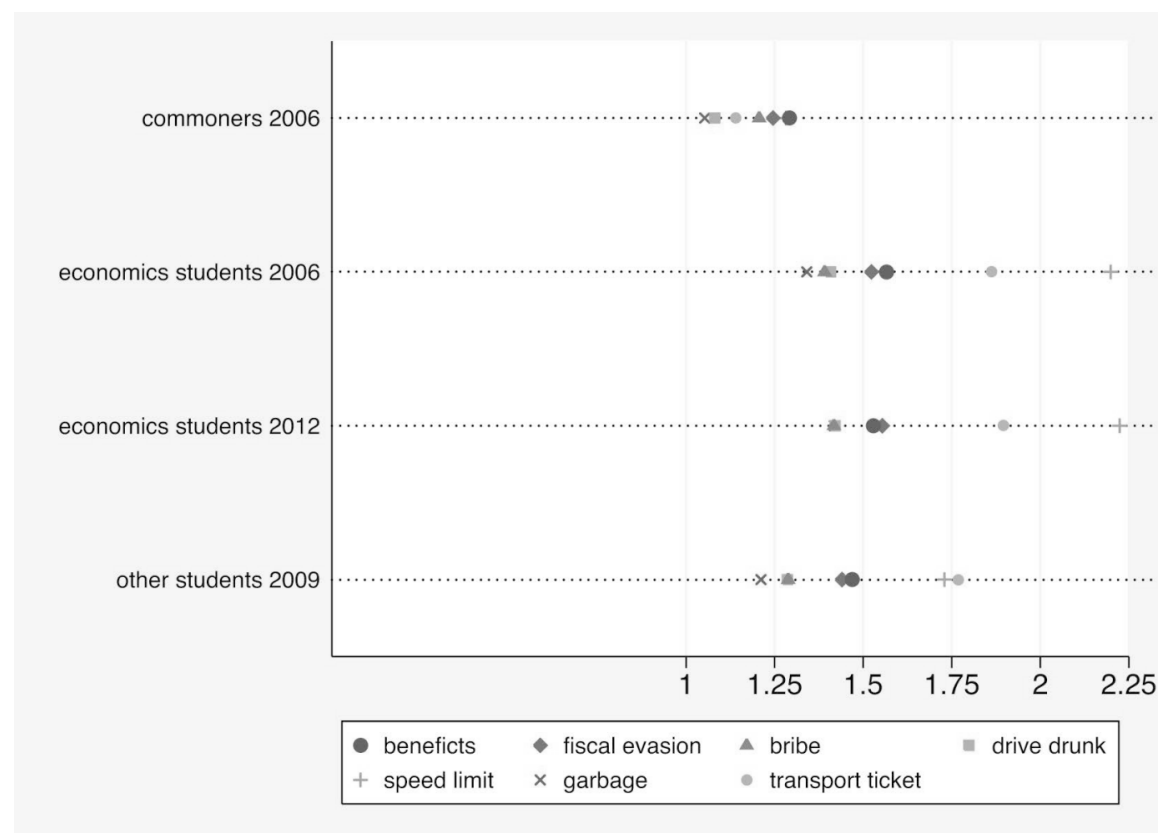

Figure 5 Dot plots among means for legitimacy recognized to free-riding

For all the cases, we can reject both the hypothesis of equal means (F test) and the hypothesis of equal variances (Bartlett's test). The Scheffé test for the variable "claiming undue benefits" suggests that the differences between "economics students 2006" and "commoners 2006" means $(0,274)$, and also "economics students 2012" and "commoners 2006" means $(0,237)$, are significant at the conventional levels, but "economics students 2006" - "other students 2009" difference $(-0,097)$ and "economics students 2012" - "other students 2009" difference $(-0,059)$ are not statistically distinguishable from zero at the $10 \%$ level. Similar results were obtained for "fiscal evasion" and "avoiding paying transport ticket". We found significant differences among these means for "exceeding speed limit" and "throwing garbage". The "economics students 2012" - "other students 2009" difference is also statistically significant at the $5 \%$ level for the items "accepting bribes" and "driving drunk".

In other words, it seems legitimate to sustain, regarding the case of free-riding, the generic existence of two neatly different dimensions within the proxies used. As for avoiding paying transport tickets, for fiscal evasion and for claiming undue social benefits, "other students" follow a pattern not very dissimilar from the one of their economics colleagues of both years, being prone to a high amount of indulgence, if not sympathy, a trait that tidily separates the almost totality of scholar youngsters from the rather more aged "commoners". Instead, as regards throwing garbage in the street, accepting bribes, driving drunk and exceeding speed limits, economics apprentices are outstandingly tolerant, separating them both from older citizens and from their junior counterparts. 
This appears to indicate the presence not only of a dimension of risk-loving, sensation-seeking or indeed youth inclination for temerity, such as suggested by Graça, Lopes and Correia $(2014,2016)$, but also of two distinguishable varieties of free-ride perception. Notice that whereas in the cases of bribes, garbage throwing, drunk driving and excessive speed there is one explicit and direct component of injury done to others and/or of violation of moral norms, or a "private free-riding", so to speak, for fiscal evasion, request of undue benefits and avoidance of paying ticket the harm done is manifestly more diffuse and it refers predominantly to the society as a whole. It thus corresponds to what we may call a "public free-riding", or free-riding vis-à-vis the res publica, which is besides easily associable with the low levels of civic commitment that is also denoted by the diminished interest for politics, typical of the group of "other students". Moreover, these are obviously also conducts of the variety capable of attracting the "catch-me-if-you-can", defying response already noticed for youngsters in general.

This conclusion, albeit apparently reasonable, does however lead us somewhat oppositely to what was suggested by Gandal and Roccas (2002), regarding the fact of economics novices supposedly diverging from average students mostly by their lack of adhesion to values of universalism, yet still keeping enough benevolence to make them good neighbors, if not good citizens. Instead, in our research, values of universalism, or at least of civic virtues, seem to be rather absent from the entire juvenile population, but whereas now the "other students" apparently keep enough feelings of benevolence to make them consistently avoid hindering or jeopardizing their fellow human beings in the immediate surroundings (although probably not the more "abstract" or mentally distant commonwealth), economics students seem to simply not care: both for what is more distant and for what is more close; whether based of abstract principles, or guided by simple, direct human benevolence.

\section{Concluding remarks}

Regarding the previous tradition of studies on economists' typical values, attitudes and behaviors, we have confirmed its intrinsic analytical interest, notwithstanding the fact that this line of enquiry seems to have been largely overburdened by an apparent obsession, generating an excessive focus on the strict issues of economists' free-riding and free-marketeering propensities, added by the examination of their putative origin on either "nature" or "nurture". Other dimensions would probably be considered likewise engendering great scientific benefit, namely the ones regarding the proclivities for risk-loving and sensation-seeking, but also the adoption of power-and-achievement values, contextual influences in the formation of moral values, and similarly the relevance of peer pressure, perceived group status, social expectations referring the economic profession, as well as the broad cultural formation of its practitioners.

Previous research on the Portuguese case was used as a basis for further scrutiny, revealing a number of interesting features. Economics' students of both years (2006 and 2012) have exhibited a neat divergence when compared with the 
general population, both regarding free-riding and free-marketeering leanings, evidencing also a political self-perception making them slant to the right-wing. Other students are also somewhat more inclined to free-riding than "commoners", although to a lesser extent than economics apprentices; but instead they are considerably pro-state in matters of economic regulation, and lean consistently to the left-wing. They are, however, also considerably less interested in politics than both "commoners" and economics novices, this last group being the most politically attentive of all.

Such increased interest for politics does not stem from any possible importance genuinely recognized by economists to public issues/problems, or even from some magnified perception of citizens' capacity to influence the public affairs (in this particular case, against the assumptions made in previous works on the Portuguese reality), but instead mostly from their persuasion of being endowed with particular capacities to exercise political functions, partly given the previous "colonization" of political life by mental and rhetorical devices originating from economics, but also because of a somewhat aggrandized self-image, rendering economics trainees prone to various processes leading to their own further self-aggrandizement. This tendency of economics students to inflated self-images is arguably made fully compatible with a predominantly selfish and careerist approach to politics via the correlate influence of various other dispositions, namely the prevalence of achievement-and-power values (or the "cult of success"), and peer pressure.

The scatterplots on both interest regarding politics and self-image in left-right terms, set against free-riding proclivity, largely confirm these assumptions as to the four samples used ("commoners", "other students" and "economists" of both 2006 and 2012), politics-oriented and right-wing persuaded economists being also the most free-riding inclined of all the groups considered. Free-riding propensity was, however, far from revealing an unambiguous character. Previous studies have evidenced a fundamental difference between a more "categorical", as opposed to a merely contextual and simply "conditional" adhesion of economists to moral codes, universalism definitely not their forte, but benevolence vis-à-vis neighbors rendering them capable of moral sentiments and a moral conduct. In this study we have, however, perceived a comparative global erosion of moral values: economics' students are now highly inclined to all the varieties of free-riding considered, thus diametrically opposed to older "commoners", whereas other students tend to follow their path in aspects regarding more distant issues (such as civic values), but are rather less inclined to free-ride in aspects referring to matters involving a bigger proximity. Economics' rookies also reveal to be consistently more risk-lovers and sensation-seekers than their colleagues from other courses.

This set of problems appears to propitiate some promising further analytical treatment, appealing not only to the usual handling typical of the consecrated economists' collective self-analysis, one that focus strictly on discussing free-marketer and free-riding proclivities, arguing for the primacy of either nature of nurture, but broadening the scope of problems by summoning up the tool-boxes characteristic of other disciplinary areas, namely economic sociology, social psychology, political sociology and the sociology of professions. 


\section{References}

Bauman, Yoram, and Elaina Rose (2011), "Selection or indoctrination: why do economics students donate less than the rest?", Journal of Economic Behavior and Organization, 79 (3), pp. 318-327.

Caplan, Bryan (2002), “Systematically biased beliefs about economics: robust evidence of judgmental anomalies from the survey of Americans and economists on the economy", Economic Journal, 112 (479), pp. 433-458.

Cappelen, Alexander W., Erik Sørensen, and Bertil Tungodden (2010), “Responsibility for what? Fairness and individual responsibility", European Economic Review, 54, pp. 429-441.

Carter, John R., and Michael D, Irons (1991), "Are economists different, and if so, why?", Journal of Economic Perspectives, 5, pp. 171-177.

Chang, Ha-Joon (2011), 23 Things They Don't Tell You about Capitalism, London/Oxford/New York/New Delhi/Sydney, Bloomsbury Publishing.

Cipriani, Giam Pietro, Diego Lubian, and Angelo Zago (2009), “Natural born economists?", Journal of Economic Psychology, 30, pp. 455-468.

Deleuze, Gilles, and Félix Guattari (1987), A Thousand Plateaus, Minneapolis, University of Minnesota Press.

Delgado-Betancourth, Sandra Xinena (2014), “Rethinking economics education: challenges and opportunities", Workplace, 23, pp. 48-56.

Elegido, Juan (2009), "Business education and erosion of character", African Journal of Business Ethics, 4 (1), November, pp. 16-24.

Etzioni, Amitai (2015), "The moral effects of economic teaching", Sociological Forum, 30 (1), March, pp. 228-233, DOI: 10.1111/socf.12153.

Faravelli, Marco (2007), "How context matters: a survey based experiment on distributive justice", Journal of Public Economics, 91 (7-8), pp. 1399-1422.

Fischer, Mira, Björn Kauder, Niklas Potrafke, and Heinrich W, Ursprung (2016), “Support for free-market policies and reforms: does the field of study influence students' political attitudes?", Ifo Working Paper, No. 218, Leibniz Institute for Economic Research at the University of Munich, available at: http://hdl,handle,net/10419/145307 (last access in September 2019).

Frank, Björn, and Günther G. Schulze (1998), “How tempting is corruption? More bad news about economists", Diskussionsbeiträge aus dem Institut für Volkswirtschaftslehre, 520 (164/1998), Universität Hohenheim.

Frank, Björn, and Günther G, Schulze (2000), "Does economics make citizens corrupt?", Journal of Economic Behavior and Organization, 43, pp. 101-113.

Frank, Robert H., Thomas D, Gilovich, and Dennis T, Regan (1993), “Does studying economics inhibit cooperation?", Journal of Economic Perspectives, 7, pp. 159-171.

Frank, Robert H., Thomas D, Gilovich, and Dennis T, Regan (1996), “Do economists make bad citizens?", Journal of Economic Perspectives, 10, pp. 187-192.

Frey, Bruno S. (1986), "Economists favour the price system - who else does?", Kyklos, 39, pp. 537- 563.

Frey, Bruno S., Werner W, Pommerehne, and Beat Gygi (1993), “Economics indoctrination or selection? Some empirical results", Journal of Economic Education, 24, pp. 271-281. 
Frey, Bruno S., and Stephan Meier (2003), “Are political economists selfish and indoctrinated? Evidence from a natural experiment", Economic Inquiry, 41, pp. 448-462.

Frey, Bruno S., and Stephan Meier (2004), "Pro-social behavior in a natural setting", Journal of Economic Behavior and Organization, 54, pp. 65-88.

Frey, Bruno S., and Stephan Meier (2005), "Selfish and indoctrinated economists?", European Journal of Law and Economics, 19, pp. 165-171.

Gandal, Neil, and Sonia Roccas (2002), “Good neighbours / bad citizens: personal value priorities of economists", Discussion Paper, No, 3660, Centre for Economic Policy Research, ISSN 0265-8003.

Gandal, Neil, Sonia Roccas, Lilach Sagiv, and Amy Wrzesniewski (2004), "Personal value priorities of economists", Discussion Paper, No, 4655, Centre for Economic Policy Research, ISSN 0265-8003.

Gandal, Neil, Sonia Roccas, Lilach Sagiv, and Amy Wrzesniewski (2005), “Personal value priorities of economists", Human Relations, 58, pp. 1227-1252.

Goossens, Amélie, and Pierre-Guillaume Méon (2010), “The impact of studying economics, and other disciplines, on the belief that voluntary exchange makes everyone better off", CEB Working Paper, No, 10/012, Solvay Brussels School of Economics and Management, Centre Emile Bernheim, Université Libre de Bruxelles.

Graça, João Carlos (2012), “Acerca da instabilidade da condição da sociologia económica", Análise Social, XLVI (202), pp. 4-27.

Graça, João Carlos, João Carlos Lopes, and Rita Gomes Correia (2014), “Economics education: literacy or mind framing? Evidence from a survey on the social building of trust in Portugal", Working-Paper, Department of Economics working-paper series, ISEG, Lisbon University, December, available at: https://aquila5,iseg,ulisboa.pt/aquila/getFile,do?method=getFile\&fileId=531131\&_r equest_checksum_=9e88fae7f14a46d57b4d74ef4bf190d83bca64e6 (last access: December 28, 2017).

Graça, João Carlos, João Carlos Lopes, and Rita Gomes Correia (2016), “Economics education: literacy or mind framing? Evidence from a survey on the social building of trust in Portugal", Análise Social, LI (220), pp. 516-542, ISSN online 2182-2999, available at: http://analisesocial,ics,ul.pt/documentos/AS_220_art01,pdf (last access in September 2019).

Haucap, Justus, and Tobias Just (2003), “Not guilty?: Another look at the nature and nurture of economics students", Diskussionspapier, No. 8,

Helmut-Schmidt-Universität, Hamburg, Fächergruppe Volkswirtschaftslehre, available at: http://hdl,handle,net/10419/23526 (last access in September 2019).

Haucap, Justus, and Tobias Just (2004), “Not guilty? Another look at the nature and nurture of economics students, European Journal of Law and Economics, 29, pp. 239-254.

Hellmich, Simon (2012), "State of the art: are economists selfish and rational? And if so, why?", Working Paper, No. 4, Universität Bielefeld, Fakultät für Soziologie, Didaktik der Sozialwissenschaften.

Hertel, Guido, Henk Aarts, and Marcel Zeelenberg (2002), “What do you think is 'fair'? Effects of ingroup norms and outcome control on fairness judgments", European Journal of Social Psychology, 32, pp. 327-341. 
Hodgson, Geoffrey M, (2004), “Opportunism is not the only reason why firms exist: why an explanatory emphasis on opportunism may mislead management strategy", Industrial and Corporate Change, 13 (2), pp. 401-418.

Hole, Astri Drange (2013), "How do economists differ from others in distributive situations?", Nordic Journal of Political Economy, 38 (4), pp. 1-30, available at: https://ideas,repec,org/a/noj/journl/v37y2013p4,html (last access in September 2019).

Hummel, Katrin, Dieter Pfaff, and Katja Rost (2016), “Does economics and business education wash away moral judgment competence?", Journal of Business Ethics, DOI: $10.1007 / \mathrm{s} 10551-016-3142-6$.

Kahneman, Daniel A., Jack L, Knetsch, and Richard H, Thaler (1986), “Fairness and the assumptions of economics", Journal of Business, 59, pp. S286-S300.

Kearl, J, R., Clayne L., Pope, Gordon C, Whiting, G. C., and Larry T, Wimmer (1979), "A confusion of economists?", American Economic Review, 69, pp. 29-37.

Kirchgässner, Gebhard (2005), "(Why) Are economists different?", European Journal of Political Economy, 21, pp. 543-562.

Kirchgässner, Gebhard (2014), “On self-interest and greed”, Discussion Paper, No. 2014-16, School of Economics and Political Science, University of St, Gallen.

Konow, James (2014), “Can economic ethics be taught?”, Discussion Paper, August 2014, University of Kiel.

Laband, David N., and Richard O. Beil (1999), "Are economists more selfish than other 'social' scientists?", Public Choice, 100, pp. 85-101.

Lanteri, Alessandro (2008), “(Why) do selfish people self-select in economics?", Erasmus Journal for Philosophy and Economics, 1 (1), Autumn: pp. 1-23, available at: http://ejpe,org/pdf/1-1-art-1,pdf (last access September 2019).

Latour, Bruno (1999), Pandora's Hope: Essays on the Reality of Science Studies, Cambridge, MA, Harvard University Press.

Latour, Bruno (2010), On the Modern Cult of the Factish Gods, Durham, NC, Duke University Press.

Lazear, Edward P. (2000), “Economic imperialism”, Quarterly Journal of Economics, 115, pp. 99-146.

Lebaron, Frédéric (2012), "A formação dos economistas e a ordem simbólica mercantil”, REDD - Revista Espaço de Diálogo e Desconexão, Araraquara, Brazil, 4 (2), jan,/jul.

López-Pérez, Raúl, and Eli Spiegelman (2012), “Do economists lie more?”, Working Paper, No. 4/2012, Economic Analysis - working paper series, Universidad Autonoma de Madrid.

Macpherson, Crawford Brough (1962), The Political Theory of Possessive Individualism, Hobbes to Locke, Oxford, Oxford University Press.

Marques, Rafael (2003), “Introdução: os trilhos da nova sociologia económica”, em Rafael Marques and João Peixoto (orgs,) (2003), A Nova Sociologia Económica, Oeiras, Celta Editora, pp. 1-67.

Marwell, Gerald, and Ruth E, Ames (1981), “Economists free ride, does anyone else?: Experiments on the provision of public goods, IV", Journal of Public Economics, 15, pp. 295-310.

Mautz, Felipe Correa (2014), “El pensamiento de los estudiantes de economía en Chile", Santiago, Universidad de Chile, thesis to qualify for the Master in Economic Analysis. 
Meier, Stephan, and Bruno S, Frey (2004), “Do business students make good citizens?", International Journal of the Economics of Business, 11, pp. 141-163.

Myrdal, Gunnar (1954), The Political Element in the Development of Economic Thought, Cambridge, MA, Harvard University Press.

Núñez, Javier, Leslie Miranda, and Javier Scavia (2007), “El impacto de estudiar Economía sobre la cooperación social: evidencia experimental de estudiantes chilenos", Serie Documentos de Trabajo, No, 260, Departamento de Economía, Universidad de Chile.

Rowen, Donna, and Michael Dietrich (2007), "Attitudes and motivations of Economics students: some recent evidence", Working Paper, Department of Economics, Sheffield Economic Research Paper Series, No. 2007007, University of Sheffield.

Rubinstein, Ariel (2006), "A sceptic's comment on the study of economics", The Economic Journal, 116, pp. C1-C9.

Scott, James H., Mitchell P, Rothman (1975), "The effect of an introductory economics course on student political attitudes", Journal of Economic Education, 6, pp. 107-112.

Selten, Reinhard, and Axel Ockenfels (1998), “An experimental solidarity game”, Journal of Economic Behavior \& Organization, 3 (4), pp. 517-539.

Simon, Herbert A. (1993), "Altruism and economics", American Economic Review, 83, pp. 156-161.

Sjöberg, Lennart, and Elisabeth Engelberg (2006), “Attitudes to economic risk-taking, sensation seeking and values of business students specializing in finance", SSE/EFI Working Paper, series in Business Administration, No, 2006:3, Stockholm, Center for Risk Research, Stockholm School of Economics.

Stigler, George J. (1959), “The politics of political economists”, Quarterly Journal of Economics, 73, pp. 522-532.

Stigler, George J. (1982), The Economist as Preacher, and Other Essays, Chicago, The University of Chicago Press.

Varoufakis, Yanis (2002 [1998]), Foundations of Economics: A Beginner's Companion, London and New York, Taylor \& Francis e-Library.

Wang, Long, and J, Keith Murnighan (2009), "Economics and greed", presented at the 22 ${ }^{\text {nd }}$ Annual International Association of Conflict Management Conference, Kyoto, Japan, 15-18 June, available at: https://www.researchgate.net/publication/228182013_Economics_and_Greed (last access September 2019).

Wang, Long, Deepak Malhotra, and J, Keith Murnighan (2011), “Economics education and greed", Academy of Management Learning E Education, 10, pp. 643-660.

Williamson, Oliver E, (1975), Markets and Hierarchies: Analysis and Anti-Trust Implications, A Study in the Economics of Internal Organization, New York, Free Press.

Yezer, Anthony M., Robert S, Goldfarb, and Paul J, Popen (1996), “Does studying economics discourage cooperation? Watch what we do, not what we say or how we play", Journal of Economic Perspectives, 10, pp. 117-186. 


\section{Reconhecimento e agradecimento}

This work was supported by FCT, I.P., the Portuguese national funding agency for science, research and technology, under the Project UID/SOC/04521/2019.

João Carlos Graça. Professor auxiliar com agregação, Universidade de Lisboa, Instituto Superior de Economia e Gestão (ISEG), Departamento de Ciências Sociais, Centro de Investigação em Ciências Sociais e Gestão (Socius/CSG), Lisboa, Portugal, E-mail: jgraca@iseg.ulisboa.pt e jogra1958@netcabo.pt

Jorge Caiado. Professor auxiliar, Universidade de Lisboa, Instituto Superior de Economia e Gestão (ISEG), Departamento de Matemática, Centro de Matemática Aplicada à Previsão e Decisão Económica (Cemapre), Lisboa, Portugal, E-mail: jcaiado@iseg.ulisboa.pt

Rita Gomes Correia. Investigadora, Universidade de Lisboa, Instituto Superior de Economia e Gestão (ISEG), Centro de Investigação em Ciências Sociais e Gestão (Socius/CSG), Lisboa, Portugal, E-mail: ritagomescorreia@yahoo.com

Receção: 30 de dezembro de 2017 Aprovação: 24 de maio de 2018 